\title{
Impact of Power Transformer Insulating Mineral Oil Degradation on FRA Polar Plot
}

\author{
Omar M Aljohani, Ahmed Abu-siada \\ Electrical and Computer Engineering Department \\ Curtin University \\ Perth, Australia \\ omaljohani@hotmail.com and a.abusiada@curtin.edu.au
}

\begin{abstract}
Frequency response analysis (FRA) has been employed as an effective tool for the detection of various mechanical winding and core deformations within electrical power transformer. Traditional FRA signature interpretation relies on the magnitude of the FRA plot although all practical frequency response analyzers are able to provide both magnitude and angle of the FRA signal in wide frequency range. Moreover, no attention has been given to the impact of power transformer insulating oil degradation on the FRA signature. This paper presents is aimed at introducing a new interpretation approach of the FRA signature using polar plot which is obtained by incorporating FRA signature magnitude and phase into one plot. The paper also investigates the impact of insulating mineral oil degradation on the proposed polar plot signature. Digital image processing (DIP) technique is developed to automate the interpretation process. In this regard, the physical geometrical dimension of a single-phase transformer filled with insulating mineral oil is simulated using three-dimensional finite element analysis to emulate real transformer operation. FRA polar plot signatures are measured and analyzed for various health conditions of the mineral oil. Results show that insulating mineral oil degradation has an impact on the transformer FRA polar plot signature. The proposed FRA polar plot technique is easy to implement within any frequency response analyzer.
\end{abstract}

Keywords-power transformer; Mineral insulating oil; Frequency response analysis; Polar plot; Digital Image Processing.

\section{INTRODUCTION}

The bulk of global power transformers were commenced into service prior to 1980 and as a result they are approaching or have already exceeded their proposed design life [1-3]. The likelihood of failures is significantly increasing with transformer aging, consequently it is an essential to adopt a reliable diagnostic tool to identify the current health condition and to take timely and proper remedial action to avoid any possible catastrophic failures [2, 4-6]. Various diagnostic techniques are currently used worldwide to detect faults within power transformers [7-10]. Among these techniques, frequency response analysis (FRA) has been widely recognized as the most reliable tool to diagnose mechanical deformation within power transformers $[11,12]$. FRA is based on the fact that transformer components including the core, windings and insulation can be modelled as a network of capacitance, resistance, and self and mutual inductances whose values change when internal mechanical deformation takes place within the transformer. This change can be detected externally through the variation in the resonance frequencies of the transformer FRA signature. Transformer insulation dielectric characteristics deteriorate over time due to oil/paper degradation and moisture ingress which may have an impact on the transformer FRA signature as well [13]. FRA testing is conducted by applying a sweep variable frequency AC voltage of low amplitude to one terminal of a transformer winding and measuring the response voltage across the other terminal of the winding with reference to the tank $[4,14]$. The measured FRA signature could be in the form of impedance, admittance, or transfer function $\left(\mathrm{V}_{\text {out }} / \mathrm{V}_{\text {input }}\right.$ in $\left.\mathrm{dB}\right)$ as a function of wide frequency range. Because FRA signatures relies on graphical analysis, interpretation process is a highly specialised area that motivated researchers to investigate the impact of various mechanical winding deformations on the FRA signature in order to develop stander codes for FRA signature identification and quantification [15-17]. While transformer FRA signature is provided as magnitude and phase angle of the measured signal, only magnitude is currently used for signal interpretation. Furthermore, no attention has been given to investigate the impact of insulating oil condition on the FRA signature. This paper introduces a new approach for FRA signature interpretation by incorporating both magnitude and phase angle of the measured signal in one polar plot that exhibits most of the measured signal features and facilitate the use of digital image processing (DIP). The new approach is used to investigate the impact of mineral insulating oil degradation on the transformer FRA signature.

\section{TRANSFORMER MINERAL OIL INSULATION}

The insulation system within power transformers consists of paper insulation immersed in insulating oil which involves different physical, dielectric, and thermal properties. Mineral oil is the most popular fluid used for insulating electrical equipment, such as power transformers [1]. Researchers have attempted to improve the technical attributes of mineral oil to overcome some of its drawbacks which include a lack of ecofriendliness and the expected increase in its price due to the shortage of petroleum products [1,2]. Various characteristics of mineral oil as a transformer dielectric are listed in Table A-I in the Appendix [1-6]. Due to the high electrical and thermal 
stresses that in-service transformers exhibit, paper and oil decomposition takes place causing a change in oil dielectric properties such as oil break down voltage, acidity, viscosity, conductivity, and permittivity. Oil deterioration can be simulated by changing some of the oil dielectric characteristics such as conductivity and permittivity. While dielectric permittivity $(\varepsilon)$ affects insulation material behavior under transient electrical conditions, electric conductivity $(\sigma)$ is a vital oil characteristic which specifies the dielectric strength of insulating oil [3]. The electrical conductivity of mineral oil can be assessed to evaluate oil health condition and aging [7]. Because variations in dielectric permittivity and electrical conductivity have a significant effect on the oil capacitance [8], oil degradation/aging is expected to affect the transformer FRA signature particularly in the high frequency range.

\section{FINITE ELEMENT ANALYSIS}

Finite element analysis (FEA) has been utilized as a physical environment to emulate different dynamic systems such as power transformer [9]. In this paper, the physical dimension for a single-phase transformer is simulated using FEA, as shown in Fig.1 (all specifications/dimensions are given in Table A-II in the Appendix). The 3D transformer model shown in Fig. 2 is solved in magneto-static and electrostatic solvers using Maxwell's equations to extract the inductance, and capacitance matrices of the relevant transformer components. Resistance and conductance calculations are carried out by applying the eddy current, magnetic transient and electric DC conduction solvers.

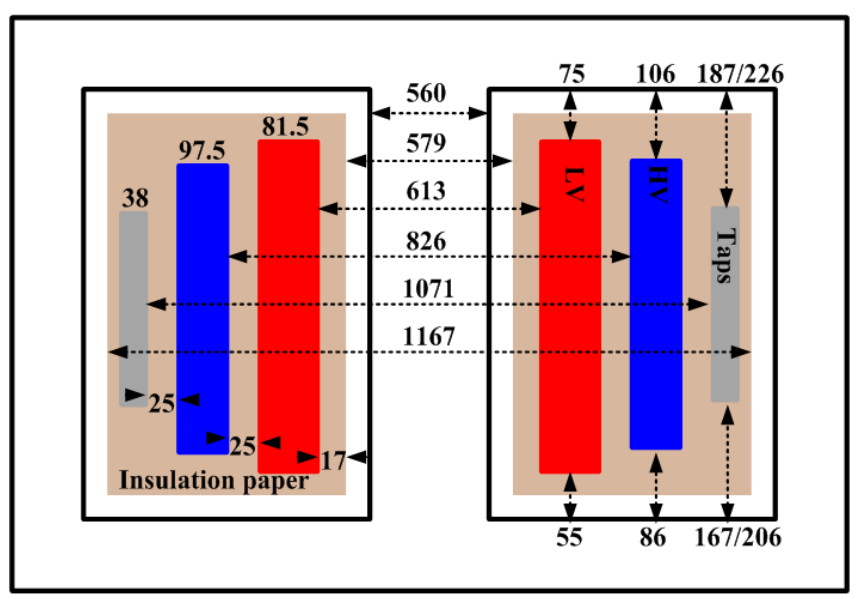

Fig. 1. Schematic diagram of the investigated transformer model (all dimensions are in $\mathrm{mm}$ ).

Transformer parameters were calculated using FEA and used to simulate the high frequency equivalent electrical transformer model shown in Fig. 3. This model comprises series inductance $\left(L_{s}\right)$, and series resistance $\left(R_{s}\right)$, representing the high voltage (HV) and low voltage (LV) windings. Winding insulation is modeled by shunt capacitance $\left(\mathrm{C}_{\mathrm{sh}}\right)$ and conductance $\left(\mathrm{G}_{\mathrm{sh}}\right)$. Mutual inductances $(\mathrm{M})$ between relevant coils are also simulated. The insulation between the $\mathrm{HV}$ and $\mathrm{LV}$ windings is modeled by series capacitance $\left(\mathrm{C}_{\mathrm{HL}}\right)$ shunted by dielectric conductance $\left(\mathrm{G}_{\mathrm{HL}}\right)$. Series capacitances $\left(\mathrm{C}_{\mathrm{HO}}\right)$,
$\left(\mathrm{C}_{\mathrm{L} 0}\right)$ shunted by dielectric conductances $\left(\mathrm{G}_{\mathrm{H} 0}\right),\left(\mathrm{G}_{\mathrm{L} 0}\right)$, model the dielectric insulation between $\mathrm{HV} / \mathrm{LV}$ windings and the earthed tank / core, respectively.
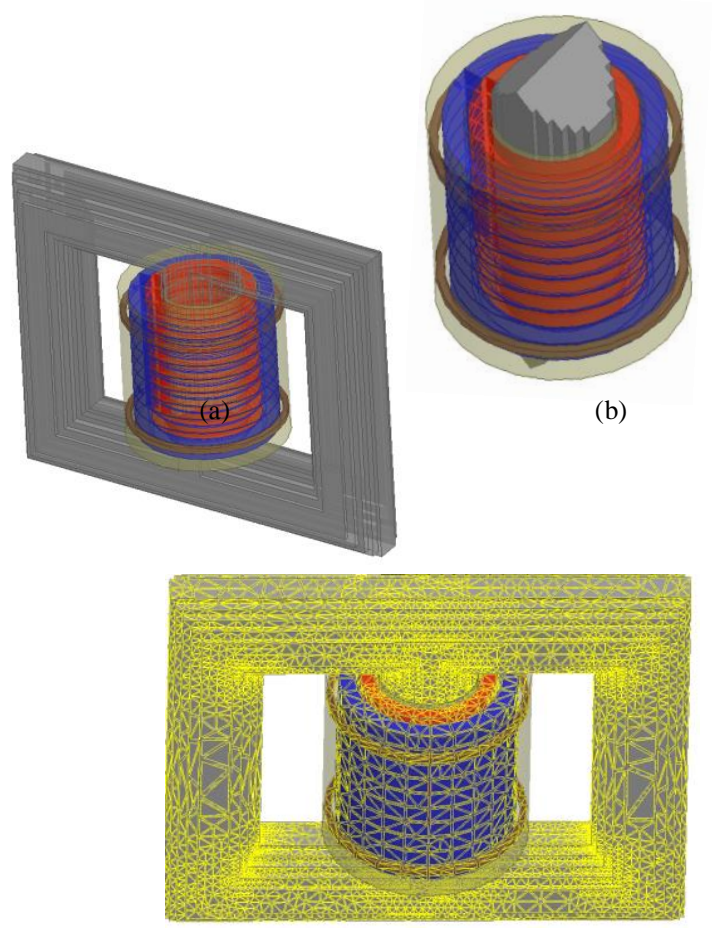

(c)

Fig. 2. (a) 3D transformer model, (b) Single leg with coils and insulation paper, and (c) Meshed entire model.

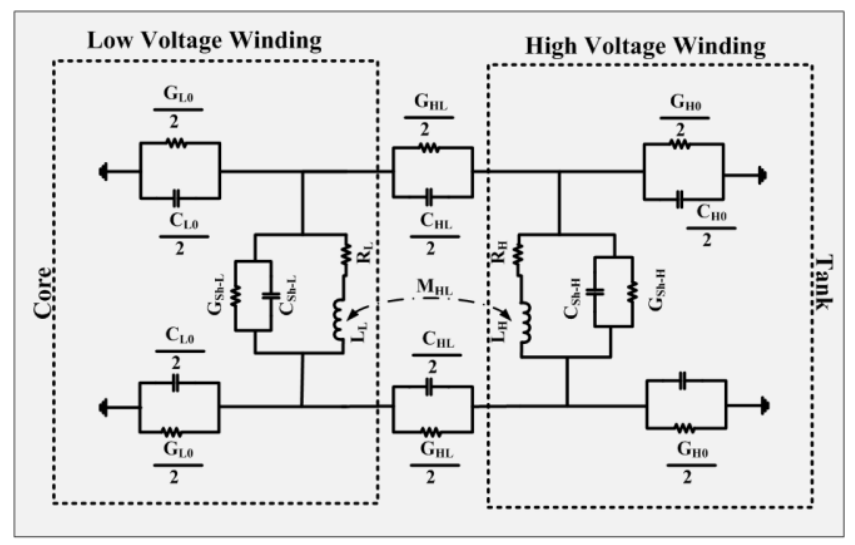

Fig. 3. Transformer distributed parameters model.

Parameters of the transfer function of the transformer model shown in Fig. 3 are obtained using FEA of the 3D transformer model of Fig. 2 as briefly illustrated below:

Capacitive component calculation is carried out using the electro-static solver where voltage $\mathrm{v}$ is applied on one conductor, while the voltage level is maintained at a level of zero on the other conductor. The electrostatic field energy (w) between the two conductors can be calculated as follows [1012]:

$$
\mathrm{W}_{\mathrm{ij}}=0.5 \int_{\Omega} \mathrm{D}_{\mathrm{i}} \times \mathrm{E}_{\mathrm{j}} \mathrm{d} \Omega
$$


Where $W_{i j}$ is the electrical field energy between conductors $i$ and $j, D_{i}$ is the electrical flux density of conductor $i$ and $E_{j}$ is the electrical field intensity of conductor $\mathrm{j}$.

The capacitance $C$ between two conductors $\mathrm{i}_{\mathrm{i}}$ and $\mathrm{j}_{\mathrm{j}}$ can then be calculated as:

$$
\mathrm{C}=2 \times \mathrm{W}_{\mathrm{ij}} / \mathrm{v}^{2}
$$

Inductive components are calculated based on the average of the magnetic field energy $\left(\mathrm{W}_{\mathrm{ij}}\right)$ and the corresponding peak current passing through the winding $\left(\mathrm{I}_{\mathrm{p}}\right)$ as follows [12]:

$$
\begin{gathered}
\mathrm{W}_{\mathrm{AV}}=0.25 \int_{m} \mathrm{~B} \times \mathrm{Hd} m \\
\mathrm{~L}=\left(4 \times \mathrm{W}_{\mathrm{AV}}\right) /\left(\mathrm{I}_{\mathrm{p}}\right)^{2}
\end{gathered}
$$

where $\mathrm{B}$ is the magnetic field density, $\mathrm{H}$ is the magnetic field intensity, and $\mathrm{m}$ is the conductor volume.

Resistive components are calculated based on power losses $\left(\mathrm{P}_{\text {loss }}\right)$ depending on conductor conductivity $(\sigma)$ and current density $(J)$ as given in (5) and (6) below [12]:

$$
\begin{aligned}
& \mathrm{P}_{\text {loss }}=1 /(2 \times \sigma) \int_{m} J . J \mathrm{~d} m \\
& \mathrm{R}=\mathrm{P}_{\text {loss }} /\left(\mathrm{I}_{r m s}\right)^{2}
\end{aligned}
$$

Table A-III in the Appendix lists the calculated transformer equivalent circuit parameters.

\section{Proposed Polar Plot and Digital Image PROCESSING TECHNIQUE}

Fig.4 shows a typical FRA signature which comprises magnitude and phase angle of the transfer function of the HV winding. To capture most of the frequency features and to facilitate the use of DIP, both plots (magnitude /phase) are incorporated into one polar plot as shown in Fig.5. Any point on the polar plot is represented by magnitude $(r)$ and angle $(\theta)$, corresponding to a particular frequency[13]. The aim of DIP is to improve the interpretation of pictorial information using electronic devices [14, 15]. Any digital image is represented as a two-dimensional (2D) matrix, $[\mathrm{A}]_{\mathrm{X} \times \mathrm{Y}}$, which consists of a finite number of pixels with a dimension of $\mathrm{X} \times \mathrm{Y}$. In the polar plot, each point can be written as $\mathrm{a}\left(\mathrm{x}_{1}, \mathrm{y}_{1}\right)$, where $|\mathrm{a}|$ represents image intensity at point $\mathrm{a}$, and $\mathrm{x}_{1}, \mathrm{y}_{1}$ are the spatial location with respect to coordinates $\mathrm{X}$ and $\mathrm{Y}$, respectively[14]. The developed DIP is built in accordance to the following steps:

- Pre-processing the image by resizing it and adjusting the colour format [15].

- Segmentation and edge detection is used to detect a region of interest (ROI) within the processed image [14].

- Feature extraction which is the crux of DIP technique. In this paper, number of pixel (NP) of polar plot signatures is used as the image extracted feature, and is given as:

$$
\mathrm{NP}=\sum_{\mathrm{x}=0}^{\mathrm{x}-1} \sum_{\mathrm{y}=0} 0^{\mathrm{y}-1} \mathrm{a}_{\mathrm{FRA}-\mathrm{PP}}(\mathrm{x}, \mathrm{y})
$$

- The finial task is comparing the extracted feature of the current condition with the healthy condition to identify any variation in the signature.
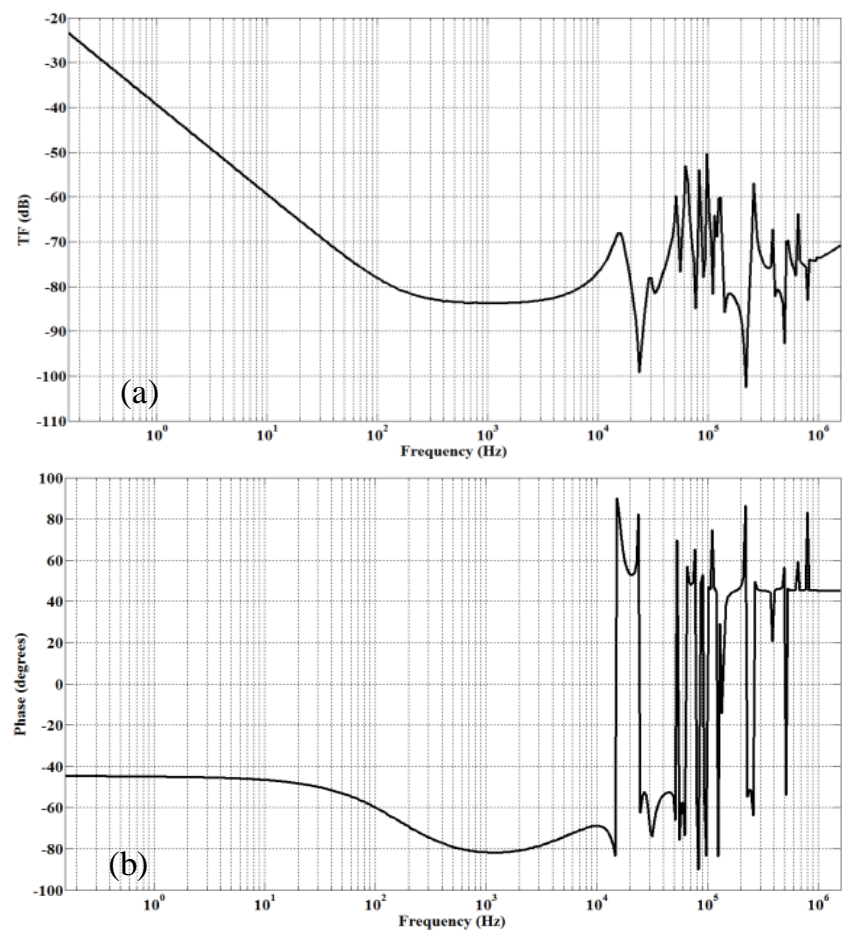

Fig. 4. Typical FRA signature for new oil insulation, (a) magnitude and (b)

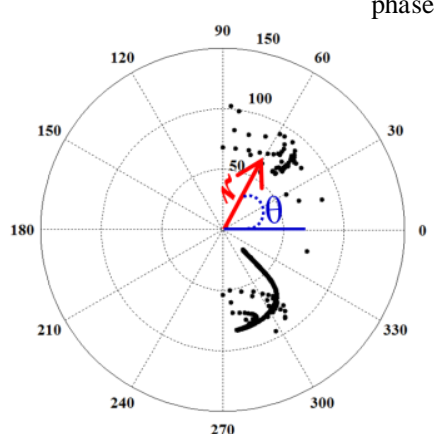

(a)

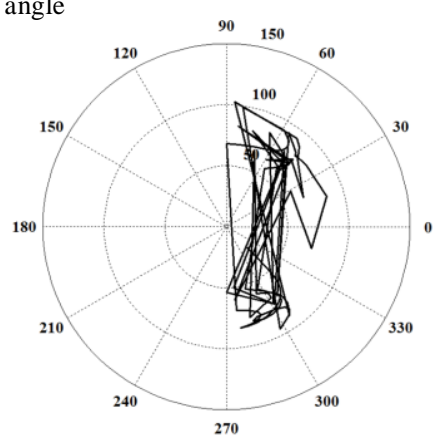

(b)
Fig. 5. Polar plot signature for new oil insulation, (a) point and (b) line.

\section{IMPACT OF INSULATION OIL DEGRADATION ON TRANSFORMER FRA POLAR PLOT SignATURE}

Mineral oil with five different levels of degradation is used to perform the analysis. The FRA polar plot signature for each oil health condition is obtained and analyzed. The transformer $\mathrm{HV}$ winding polar plot for new mineral oil insulation is shown in Fig. 5 and the extracted NP using the developed DIP technique is found to be 8,264 pixels. The high electrical and thermal stresses within operating transformers deteriorates the dielectric strength of insulation oil [16]. To show the impact of insulating oil degradation on the transformer FRA polar plot signature, the signature of the HV winding of the transformer model shown in Fig. 2 is plotted for five health conditions of transformer oil (incipient, slight, moderate, high and significant deterioration). In the model under study, oil was degraded through changing its permittivity and conductivity. The impact of each insulation oil health condition on the proposed polar plot is shown in Figs. 6 through 10. Table AIV in the Appendix shows the how those degradation levels 
are simulated by controlling oil conductivity and permittivity. Results show that, more degraded oil leads to an increase in the NP of the polar plot image as can be shown in Table I and Fig. 11.

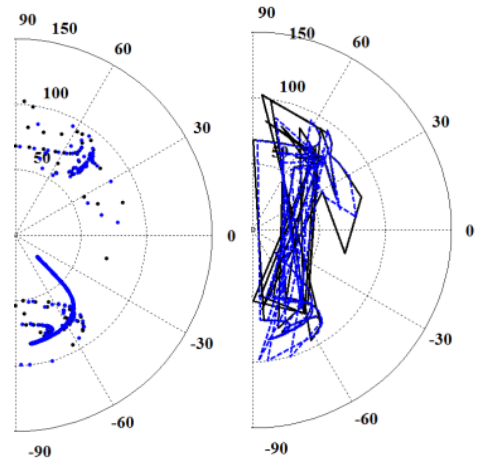

Fig. 6. Incipient oil degradation impact on polar plot signature.

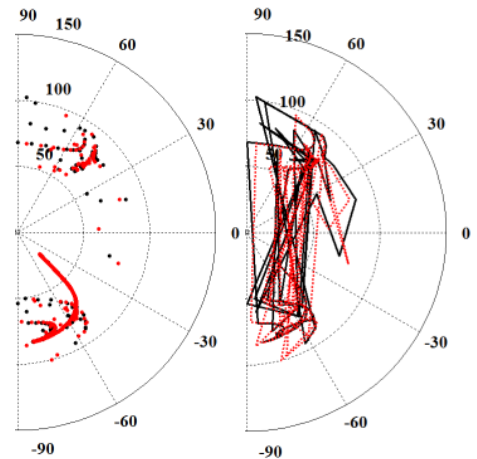

Fig. 7. Slight oil degradation impact on polar plot signature.

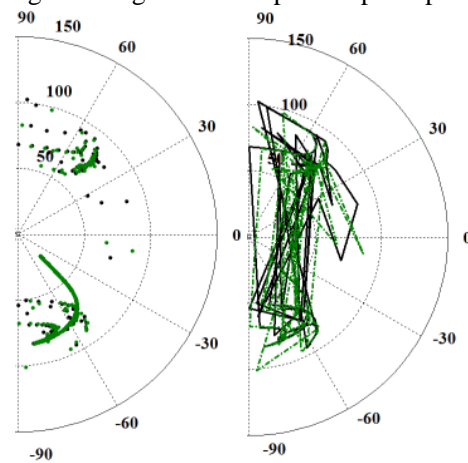

Fig. 8. Moderate oil degradation impact on polar plot signature.

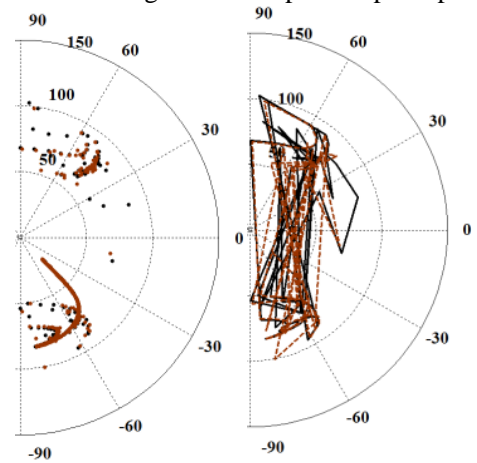

Fig. 9. High oil degradation impact on polar plot signature.

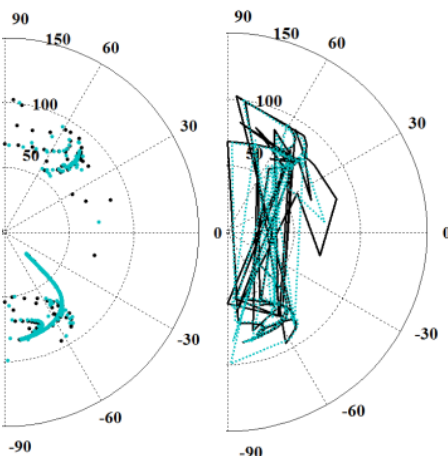

Fig. 10. Significant oil degradation impact on FRA signature.

TABLE I. NUMBER OF PIXELS FOR THE OIL DEGRADATION

\begin{tabular}{|l|l|}
\hline \multicolumn{1}{|c|}{ Oil degradation level } & \multicolumn{1}{c|}{ Number of pixels (NP) } \\
\hline New & 8264 \\
\hline Incipient & 8342 \\
\hline Slight & 8762 \\
\hline Moderate & 8823 \\
\hline High & 8995 \\
\hline Significant & 9513 \\
\hline
\end{tabular}

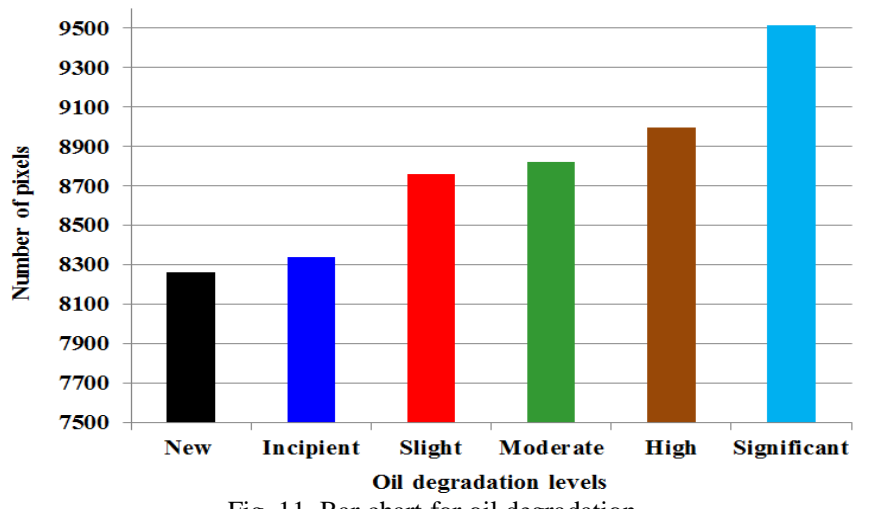

Fig. 11. Bar chart for oil degradation.

The above results show that FRA polar plots have the potential to detect transformer oil aging/degradation. Through using DIM, The effect of oil degradation is noticeable in each level of degradation according to the image number of pixels. The impact is more pronounced with the increase in the oil degradation level.

\section{CONCLUSION}

This paper introduces a new approach for frequency response (FRA) signature analysis using polar plot along with digital image processing technique (DIP). The use of polar plot is aimed at comprising most of the FRA signature features in one plot and to facilitate the use of DIP. The new proposed technique is employed to investigate the impact of insulation oil degradation on the FRA polar plot. Results show that transformer oil degradation introduces an increase in the number of pixels (NP) of the transformer FRA polar plot signature. The proposed technique can be extended to identify and quantify other mechanical faults within the power transformer. This technique is simple, reliable and easy to build within the current frequency response analyzers to automate the FRA interpretation process. 
VII. APPENDIX

TABLE A-I CHARACTERISTICS OF INSULATION OIL $[1,2,4,5]$

\begin{tabular}{|l|l|}
\hline \multicolumn{1}{|c|}{ Parameter } & \multicolumn{1}{c|}{ Mineral oil } \\
\hline Dielectric Breakdown, $\mathrm{KV}$ & $30 / 85$ \\
\hline Relative Permittivity at $25^{\circ} \mathrm{C}$ & 2.5 \\
\hline Viscosity at $0^{\circ} \mathrm{C}, \mathrm{mm}^{2} \cdot \mathrm{s}^{-1}$ & $<76$ \\
\hline Viscosity at $40^{\circ} \mathrm{C}, \mathrm{mm}^{2} \cdot \mathrm{s}^{-1}$ & $3 / 16$ \\
\hline Viscosity at $100^{\circ} \mathrm{C}, \mathrm{mm}^{2} \cdot \mathrm{s}^{-1}$ & $2 / 2.5$ \\
\hline Pour Point, ${ }^{\circ} \mathrm{C}$ & $-30 /-60$ \\
\hline Flash Point, ${ }^{\circ} \mathrm{C}$ & $100 / 170$ \\
\hline Fire Point, ${ }^{\circ} \mathrm{C}$ & $110 / 185$ \\
\hline Density at $20^{\circ} \mathrm{C}, \mathrm{kg} \cdot \mathrm{m}^{3}$ & $0.83 / 0.89$ \\
\hline Thermal Conductivity, $\mathrm{W} \cdot \mathrm{m}^{-1} \cdot \mathrm{K}^{-1}$ & $0.11 / 0.16$ \\
\hline Expansion Coefficient, $10^{-4} \cdot \mathrm{K}^{-1}$ & $7 / 9$ \\
\hline Electrical Conductivity, $\mathrm{S} \cdot \mathrm{m}^{-1}$ & $1.5 \times 10^{-10}$ \\
\hline
\end{tabular}

TABLE A-II SPECIFICATIONS AND DIMENSIONS OF THE 40MVA ONE

Phase Three-LegGed CoRe TyPe POWER TRANSFORMER MODEL

\begin{tabular}{|l|l|}
\hline \multicolumn{1}{|c|}{ Classification } & \multicolumn{1}{c|}{ Value } \\
\hline Phase & 1 \\
\hline Frequency [Hz] & 50 \\
\hline Rated power [MVA] & 40 \\
\hline Primary/Secondary voltage [KV] & $66 / 11$ \\
\hline Primary/Secondary Winding resistance [m $\Omega$ ] & $123.7 / 12.07$ \\
\hline Primary/Secondary Turns [Turn] & $1200 / 200$ \\
\hline Impedance [\%] & 13.79 \\
\hline Height of $1^{\text {st }}$ and $2^{\text {nd }}$ rows of taps [mm] & $912 / 834$ \\
\hline Height of HV winding/ LV winding [mm] & $1074 / 1136$ \\
\hline Distance of $1^{\text {st }} 2^{\text {nd }}$ row taps to yoke [mm] & $187 / 226$ \\
\hline Distance of HV/LV winding to upper yoke [mm] & $106 / 75$ \\
\hline Distance of HV/ LV winding to lower yoke [mm] & $86 / 55$ \\
\hline $\begin{array}{l}\text { Insulation thickness between HV/LV windings } \\
\text { [mm] }\end{array}$ & 25 \\
\hline Core cross-section diameter [mm] & 560 \\
\hline Insulated core cross-section diameter [mm] & 579 \\
\hline Inner diameter of HV/LV winding/ taps [mm] & $826 / 613 / 1071$ \\
\hline
\end{tabular}

TABLE A-III TRANSFORMER PARAMETERS VALUE

\begin{tabular}{|l|l|l|}
\hline \multicolumn{1}{|c|}{ Transformer parameters } & \multicolumn{1}{c|}{ HV } & \multicolumn{1}{c|}{ LV } \\
\hline Series inductance $\left(L_{s}\right)[\mu \mathrm{H}]$ & 8.91 & 8.91 \\
\hline Series resistance $\left(R_{s}\right)[\Omega]$ & 1 & 0.025 \\
\hline Shunt capacitance $\left(C_{s h}\right)[p \mathrm{~F}]$ & 61.196 & 115.53 \\
\hline Shunt conductance $\left(G_{s h}\right)[\mu \mathrm{S}]$ & 68.5 & 0.25 \\
\hline Series capacitance $\left(C_{o}\right)[p \mathrm{~F}]$ & 567.96 & 333.24 \\
\hline Dielectric conductance $\left(G_{o}\right)[\mu \mathrm{S}]$ & 68.5 & 0.25 \\
\hline Series capacitance $\left(C_{H L}\right)[p \mathrm{~F}]$ & 89.283 \\
\hline Shunted conductance $\left(G_{H L}\right)[\mu \mathrm{S}]$ & 68.5 \\
\hline
\end{tabular}

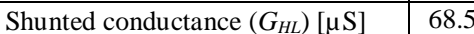

TABLE A-IV MINERAL OIL DEGRADATION LEVEL

\begin{tabular}{|l|l|l|}
\hline Degradation level & Electrical Conductivity,S.m-1 & Permittivity \\
\hline New & $1.50 \times 10^{-10}$ & 2.50 \\
\hline Incipient & $1.71 \times 10^{-10}$ & 2.75 \\
\hline Slight & $1.86 \times 10^{-10}$ & 3.00 \\
\hline Moderate & $2.02 \times 10^{-10}$ & 3.25 \\
\hline High & $2.17 \times 10^{-10}$ & 3.50 \\
\hline Significant & $2.33 \times 10^{-10}$ & 3.75 \\
\hline
\end{tabular}

\section{REFERENCES}

[1] S. Mofizul Islam, K. M. Coates, and G. Ledwich, "Identification of high frequency transformer equivalent circuit using Matlab from frequency domain data," in Industry Applications Conference, 1997. Thirty-Second IAS Annual Meeting, IAS '97., Conference Record of the 1997 IEEE, 1997, pp. 357-364 vol.1.

[2] L. M. Geldenhuis, "Power transformer life management," in Electricity Distribution, 2005. CIRED 2005. 18th International Conference and Exhibition on, 2005, pp. 1-4.
[3] E. J. Figueroa, "Managing an Aging Fleet of Transformers," in Proceeding 6th Southern Africa Regional Conference, CIGRE, 2009.

[4] A. Abu-Siada and S. Islam, "A Novel Online Technique to Detect Power Transformer Winding Faults," Power Delivery, IEEE Transactions on, vol. 27, pp. 849-857, 2012.

[5] M. A. Stephanie Uhrig, René Hummel, and Michael Krueger, "Advanced Methods for Insulation Diagnostics on Power Transformers," 3 March 2014.

[6] J. Chong and A. Abu-Siada, "A novel algorithm to detect internal transformer faults," in Power and Energy Society General Meeting, 2011 IEEE, 2011, pp. 1-5.

[7] J. A. S. B. Jayasinghe, Z. D. Wang, P. N. Jarman, and A. W. Darwin, "Investigations on sensitivity of FRA technique in diagnosis of transformer winding deformations," in Electrical Insulation, 2004 Conference Record of the 2004 IEEE International Symposium on, 2004, pp. 496-499.

[8] B. Cahyono, A. Pharmatrisanti, Y. Tamsir, Sumaryadi, and R. Siregar, "Thermal monitoring on power transformers," in Condition Monitoring and Diagnosis, 2008. CMD 2008. International Conference on, 2008, pp. 482-484.

[9] W. Ma and F. Cheng, "Research on the influence of microorganism on TAN \&\#x03B4; of power transformer oil," in Power Engineering and Automation Conference (PEAM), 2011 IEEE, 2011, pp. 301-304.

[10] K. Kwang-Hwa, S. Jong-Ho, Y. Sang-Hwa, S.-B. Han, and K. DongSik, "Study on the On-line PD Measurement Technology for Power Transformer," in Properties and applications of Dielectric Materials, 2006. 8th International Conference on, 2006, pp. 570-574.

[11] J. A. S. B. Jayasinghe, Z. D. Wang, P. N. Jarman, and A. W. Darwin, "Winding movement in power transformers: a comparison of FRA measurement connection methods," Dielectrics and Electrical Insulation, IEEE Transactions on, vol. 13, pp. 1342-1349, 2006.

[12] N. Abeywickrama, Y. V. Serdyuk, and S. M. Gubanski, "Effect of Core Magnetization on Frequency Response Analysis (FRA) of Power Transformers," Power Delivery, IEEE Transactions on, vol. 23, pp. $1432-1438,2008$

[13] M. Bagheri, M. S. Naderi, T. Blackburn, and B. T. Phung, "Dean-Stark vs FDS and KFT methods in moisture content recognition of transformers," in Power and Energy (PECon), 2012 IEEE International Conference on, 2012, pp. 712-717.

[14] H. Firoozi, M. Kharezi, H. Rahimpour, and M. Shams, "Transformer Fault Diagnosis Using Frequency Response Analysis - Practical Studies," in Power and Energy Engineering Conference (APPEEC), 2011 Asia-Pacific, 2011, pp. 1-4.

[15] CIGER, "Mechanical-condition assessment of transformer windings using Frequency Response Analysis (FRA)," in Tutorial of Cigre WG A2.26 Convener, ed. Patrick Picher, Canada: CIGER, 2007, p. 21.

[16] S. D. Mitchell and J. S. Welsh, "Modeling Power Transformers to Support the Interpretation of Frequency-Response Analysis," Power Delivery, IEEE Transactions on, vol. 26, pp. 2705-2717, 2011.

[17] J. C. Gonzales Arispe and E. E. Mombello, "Detection of Failures Within Transformers by FRA Using Multiresolution Decomposition," Power Delivery, IEEE Transactions on, vol. 29, pp. 1127-1137, 2014

[18] M. Ş. VIHACENCU, A. CIURIUC, and L. Marius, "Experimental Study of Electrical Properties of Mineral and Vegetable Transformer Oils," in International Conference on Innovation and Engineering Research, 2013, pp. 2-4

[19] Y. B. a. L. C. Hoang, "VEGETABLE OILS AS SUBSTITUTE FOR MINERAL INSULATING OILS IN MEDIUM-VOLTAGE EQUIPMENTS," CIGRE, FRANCE2007 2004.

[20] T. Judendorfer, A. Pirker, and M. Muhr, "Conductivity measurements of electrical insulating oils," in Dielectric Liquids (ICDL), 2011 IEEE International Conference on, 2011, pp. 1-4.

[21] M. Spohner, "COMPARISON OF MINERAL OIL WITH NATURAL AND SYNTHETIC OILS."

[22] K. Yasuda, S. Arazoe, T. Igarashi, S. Yanabu, G. Ueta, and S. Okabe, "Comparison of the insulation characteristics of environmentallyfriendly oils," Dielectrics and Electrical Insulation, IEEE Transactions on, vol. 17, pp. 791-798, 2010. 
[23] J. Jung-Il, A. Jung-Sik, and H. Chan-Su, "Accelerated aging effects of mineral and vegetable transformer oils on medium voltage power transformers," Dielectrics and Electrical Insulation, IEEE Transactions on, vol. 19, pp. 156-161, 2012

[24] L. V. Badicu, B. Gorgan, L. M. Dumitran, and P. V. Notingher, "Assessment of transformer mineral oil condition based on $\mathrm{dc}$ and ac conductivity," Dielectrics and Electrical Insulation, IEEE Transactions on, vol. 19, pp. 1544-1551, 2012.

[25] M. Bagheri, B. T. Phung, and T. Blackburn, "Influence of temperature and moisture content on frequency response analysis of transformer winding," Dielectrics and Electrical Insulation, IEEE Transactions on, vol. 21, pp. 1393-1404, 2014.

[26] M. R. Barzegaran, M. Mirzaie, and A. S. Akmal, "Investigating shortcircuit in power transformer winding with quasi-static finite element analysis and circuit-based model," in Transmission and Distribution Conference and Exposition, 2010 IEEE PES, 2010, pp. 1-8.

[27] "Ansoft Maxwell," REV 6.0 ed. Canonsburg: ANSYS Inc., 2012, p. 1006.
[28] A. Hyun-Mo, L. Ji-Yeon, K. Joong-Kyoung, O. Yeon-Ho, J. Sang-Yong, and H. Sung-Chin, "Finite-Element Analysis of Short-Circuit Electromagnetic Force in Power Transformer," Industry Applications, IEEE Transactions on, vol. 47, pp. 1267-1272, 2011

[29] Z. Haijun, Y. Bin, X. Weijie, W. Shuhong, W. Guolin, H. Youpeng, et al., "Dynamic Deformation Analysis of Power Transformer Windings in Short-Circuit Fault by FEM," Applied Superconductivity, IEEE Transactions on, vol. 24, pp. 1-4, 2014.

[30] O. Aljohani and A. Abu-Siada, "Application of FRA polar plot technique to diagnose internal faults in power transformers," in PES General Meeting | Conference \& Exposition, 2014 IEEE, 2014, pp. 1-5.

[31] R. C. Gonzalez, Digital image processing / Rafael C. Gonzalez, Richard E. Woods. Upper Saddle River, N.J.: Upper Saddle River, N.J. Pearson/Prentice Hall, 2008.

[32] A. McAndrew, "An introduction to digital image processing with matlab notes for SCM2511 image processing," School of Computer Science and Mathematics, Victoria University of Technology, pp. 1-264, 2004.

[33] A. Abu-Siada, S. Hmood, and S. Islam, "A new fuzzy logic approach for consistent interpretation of dissolved gas-in-oil analysis," Dielectrics and Electrical Insulation, IEEE Transactions on, vol. 20, pp. 2343-2349, 2013 


\title{
Improvement of DFIG Dynamic Performance during Intermittent Fire-Through Fault
}

\author{
Mahmoud Y. Khamaira, and A. Abu-Siada \\ Department of Electrical and Computer Engineering \\ Curtin University, Australia \\ m.khamaira@student.curtin.edu.au,A.Abusiada@curtin.edu.au
}

\begin{abstract}
The number of wind turbines connected to power grids have significantly increased during the last decade. This is mainly due to the convincing revolution in power electronic technology and the growing concern about greenhouse effect that is intensified due to the burning of fossil fuels. Variable-speed wind energy conversion systems (WECSs) such as doubly fed induction generators (DFIGs) are dominating the wind energy market due to their superior advantages over fixed-speed-based WECS which include more captured energy, less mechanical stress, and acoustical noise. DFIG is interfaced to the ac network through the gridside voltage source converter (GSC) and rotor-side RSC to enable the variable-speed operation of the wind turbine and to provide reactive power support to the ac grid during disturbance events. Converter switching malfunction such as fire-through may influence the power dispatch capability of the DFIG. In this paper, a coil is proposed to be integrated within the DFIG converters to improve dynamic performance of DFIGbased WECS during internal converter switching malfunctions such as fire-through fault. Simulation results without and with the coil connected to the system are presented.
\end{abstract}

Index Terms- Doubly Fed Induction Generator, Coil, fire-through, Wind Energy Conversion System.

\section{INTRODUCTION}

Wind power has been one of the most important renewable energy sources over the past decade. The global installed wind power capacity worldwide has significantly increased from $7.272 \mathrm{GW}$ at the end of the year 2002 to $40.56 \mathrm{GW}$ by the end of the year 2011[1]. In 2008, wind power has produced over $1 \%$ of the global electricity generation and by the year 2020 ; it is estimated to produce about $10 \%$ of the global electricity. Currently, doubly fed induction generator (DFIG) is commonly used for wind turbines over 1 MW capacity [1]. DFIG based wind energy conversion system (WECS) is gaining popularity because of its superior advantages over other wind turbine generator concepts $[2,3]$ that have seen DFIG application in large WECS reaching $55 \%$ of the worldwide total wind capacity during the year 2012 [4]. A typical configuration of DFIG wind turbine is shown in Fig. 1. Rotor side converter (RSC) and grid side converter (GSC) interface the DFIG with the grid [5]. Both converters use forced commutated power electronic switches such as insulated gate bipolar transistors (IGBT) to convert $\mathrm{AC}$ to $\mathrm{DC}$ and vice versa. A capacitor connected to the DC link of the converter acts as a DC voltage source $[6,7]$. The failure of a wind turbine to remain operational for a short time of voltage dip without tripping is referred to the low voltage ride-through (LVRT) capability of the turbine. Rotor crowbar circuit is usually used to protect the RSC, which is relatively a cheap solution with simple control $[4,8,9]$. In addition, many papers in the literature have investigated various approaches to compensate WECS reactive power during voltage fluctuation events by mainly connecting a flexible AC transmission system (FACTS) device such as static synchronous compensator (STATCOM) to the point of common coupling (PCC) [10-16]. There are however a few publications considering compensation of active power as well [17-20].

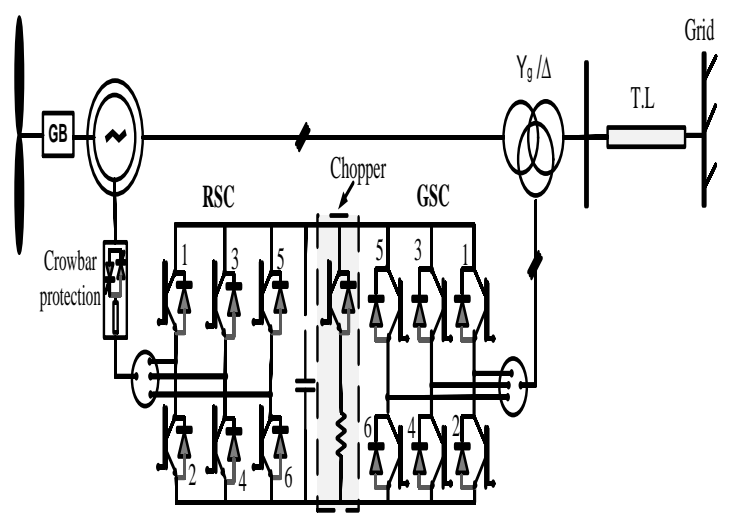

Fig. 1 Typical configuration of DFIG

This paper presents a new topology for the DFIG converters by integrating a coil to improve the overall performance of a DFIG based WECS during internal converter switching malfunctions such as firethrough fault. Simulation is carried out using Simulink/Matlab software. The contribution of this paper lies in the use of the existing DFIG converters to support active and reactive power without the need to any extra FACTS devices as stated in the literature.

\section{SYSTEM UNDER SYSTEM}

Fig. 2 shows the system under study that consists of six 1.5-MW DFIGs connected to the ac grid at the PCC. The grid that is represented by an ideal threephase voltage source of constant frequency is connected to the wind turbines via a $30-\mathrm{km}$ transmission line and step-up transformer. During normal operating conditions, reactive power produced by the wind turbines is regulated at zero MVar to maintain unity power factor connection. For an 
average wind speed of $15 \mathrm{~m} / \mathrm{s}$, which is used in this study, the turbine output active power is $1.0 \mathrm{pu}$, and the rotor shaft speed is $1.2 \mathrm{pu}$ [3]. A coil is connected to the DC link of the back-to-back power converters of the DFIG through a DC/DC chopper.

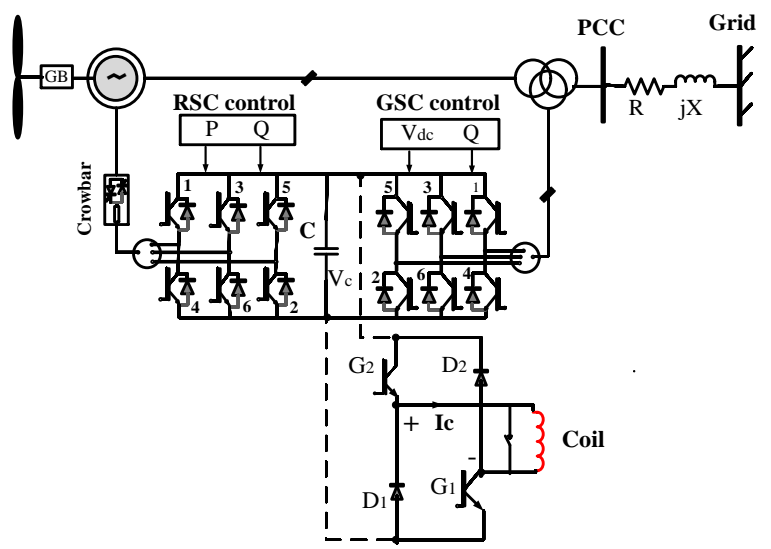

Fig. 2 Configuration of a DFIG wind turbine equipped with a coil

\section{COIL CONTROL ALGORITHM}

To control the power transfer between the coil and the DFIG system, a dc-dc chopper is used, and a fuzzy logic (FL) model is developed to control its duty cycle (D) as shown in Fig. 3. Under normal operating condition, duty cycle is maintained at 0.5 and there is no power exchange between the coil and the grid. During internal converter switching fault event that call for power support the FL controller acts to adapt the duty cycle to be in the range of 0 to 0.5 to allow the stored energy in the coil to be transferred to the grid (Discharging mode). The charging mode of the coil takes place when duty cycle is within the range of 0.5 to 1 . The relation between the voltage across the coil $\mathrm{V}_{\mathrm{c}}$ and the voltage across the dc-link capacitor Vdc can be written as $[3,21]$;

$$
\mathrm{V}_{\mathrm{c}}=(1-2 \mathrm{D}) \mathrm{V}_{\mathrm{dc}}
$$

The model is built using the graphical user interface tool provided by MATLAB. Each input is fuzzified into five sets of trimf-type membership functions (MFs). The MFs for the input variables, DFIG generated active power $\left(\mathrm{P}_{\mathrm{g}}\right)$ and the current through the coil $\left(\mathrm{I}_{\mathrm{c}}\right)$, are shown in Figs. 4(a) and (b), respectively. The MFs for the output variable, duty cycle (D), are considered on the scale from 0 to 1 as shown in Fig. 4(c). Center of gravity is used for the defuzzification process where the desired output $\mathrm{z}_{0}$ is calculated as

$$
\mathrm{z}_{0}=\frac{\int \mathrm{z} \cdot \mu_{c}(\mathrm{z}) \mathrm{dz}}{\int \mu_{c}(\mathrm{z}) \mathrm{dz}}
$$

where $\mu_{\mathrm{c}}(\mathrm{z})$ is the MF of the output

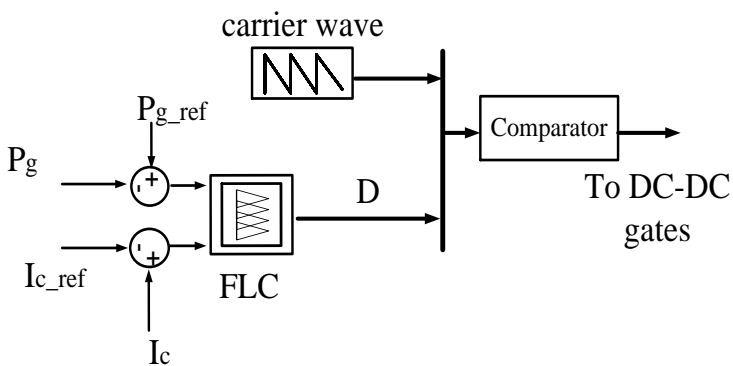

Fig. 3 Control of DC-DC chopper

The variation range in the coil current and DFIG output power, along with the corresponding duty cycle, is used to develop a set of FL rules in the form of (IF-ANDTHEN) statements to relate the input variables to the output [1].

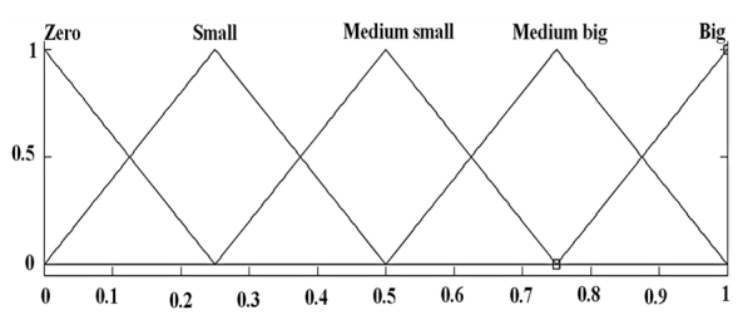

(a)

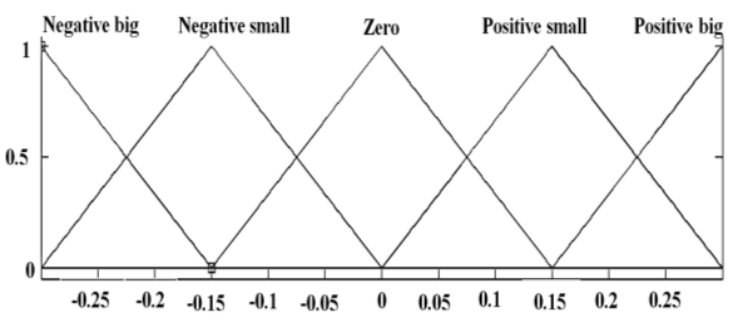

(b)

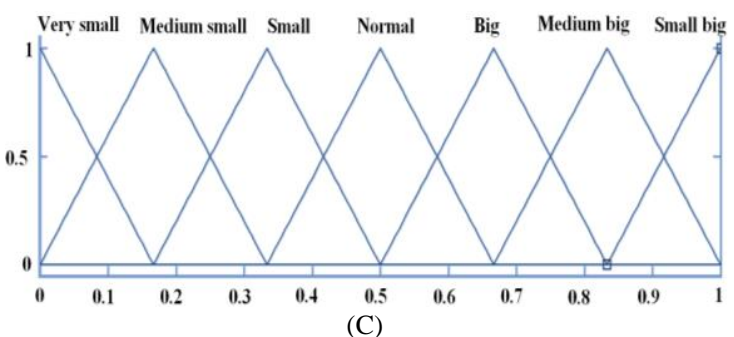

Fig. 4 Membership function for; (a) input varaiable Ic, (b) input varaiable $\mathrm{Pg}$, and (c) output variable D

\section{COIL RESPONSES DURING THE FIRE THROUGHFAULT} Coil;

There are three different modes of operation of the

\section{A. Freewheeling mode}

Freewheeling (Standby) mode is shown in Fig. 5 (a), it occurs when $D$ is equal to 0.5 . The voltage across the coil $\left(V_{c}\right)$ is equal to zero, and the $I_{c}$ is held constant at its rated value; consequently, there will be no energy transferred between the coil and the AC system, and maximum energy is stored within the coil. 
The voltage across the dc-link capacitor of the coil $\left(\mathrm{V}_{\mathrm{dc}}\right)$ is maintained at a constant level during this mode of operation. This mode will take place during normal operating condition of the WECS and after the occurrence of the fault [3].

\section{B. Discharging mode}

Fig. 5(b) shows discharging mode which will take place when the fault occurs at the grid side. In this case, the value of $\mathrm{D}$ lies in the range of $0-0.5$. When the fault occurs at $t=10 \mathrm{~s}$, the current of coil $\left(\mathrm{I}_{\mathrm{c}}\right)$ decreases, giving a negative slope (di/dt), and consequently, the voltage across the coil $\left(\mathrm{V}_{\mathrm{c}}\right)$ is turning negative. The magnitude of the voltage across the coil is controlled by the level of the duty cycle, as well as the voltage across the dc-link capacitor as given in (1). The energy stored in the coil is being delivered to the $\mathrm{AC}$ system during this mode, and the coil will be recharged at $t=10.05 \mathrm{~s}$, exactly at the time when the fault is cleared according to the rules of the designated FLC for $\mathrm{P}_{g}$ and $\mathrm{I}_{\mathrm{c}}[3]$.

\section{Charging mode}

In this mode, the coil is charged to its rated capacity. The value of $\mathrm{D}$ lies in the range of $0.5-1$, and the coil current $\left(\mathrm{I}_{\mathrm{c}}\right)$ increases, giving a positive slope (di/dt), and consequently, the voltage across the coil $\left(V_{c}\right)$ is turning positive. The energy is transferred from the system to the coil until the maximum coil energy capacity as shown in Fig.5 (c) $[1,22]$.

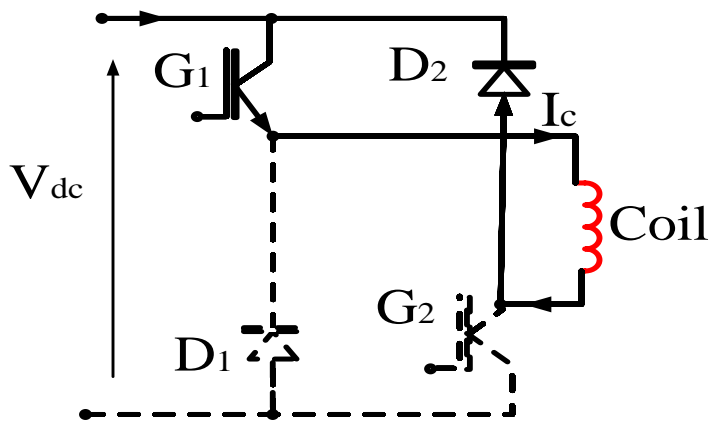

(a)

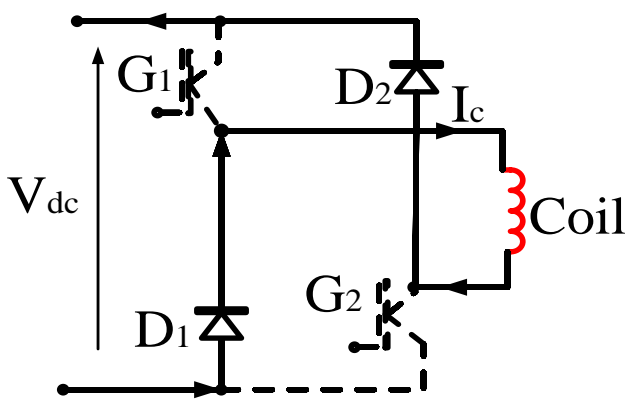

(b)

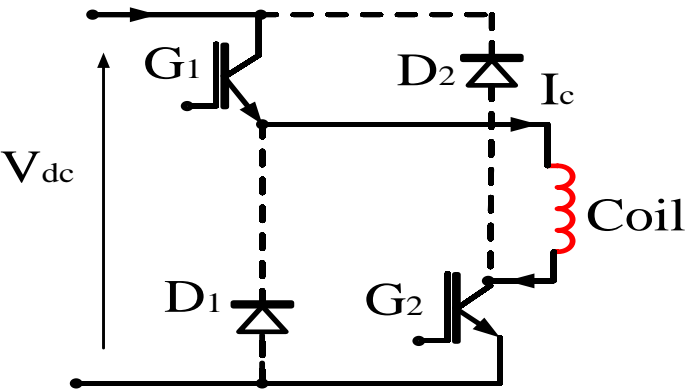

(C)

Fig. 5 Coil operation; (a) Freewheeling mode, (b) Charging mode, (c) Discharging mode

\section{V.SIMULATION RESULTS}

Intermittent fire-through is simulated within the GSC of the DFIG-based WECS shown in Fig. 2. In studied case, the fault is assumed to occur on switch $\mathrm{S} 6$ at $\mathrm{t}=10 \mathrm{~s}$ and cleared at $\mathrm{t}=10.05 \mathrm{~s}$. The model parameters are given in Tables in the Appendix.

Fig. 6 through 11 shows the dynamic response of the studied system when fire-through takes place within the GSC. The voltage profile at the point of common coupling (PCC) is shown in Fig. 6(a), where without the coil, voltage will drop to $0.185 \mathrm{pu}$ due to the fault. By integrating the coil within the DFIG converters, the dropped voltage at the PCC is raised to $0.55 \mathrm{pu}$ due to the reactive power support by the coil. Compared with the fault ride through of Spain and Germany, the voltage at the PCC violates the LVRT of the two grid codes when the coil is not connected as shown in Fig. 6(b). This will call for the disconnection of the wind turbine from the grid. However, with the coil, the amount of voltage drop decreases and reaches a safe level of the grids requirement Fig. 6(b) and therefore the wind turbine connection to the grid is maintained.

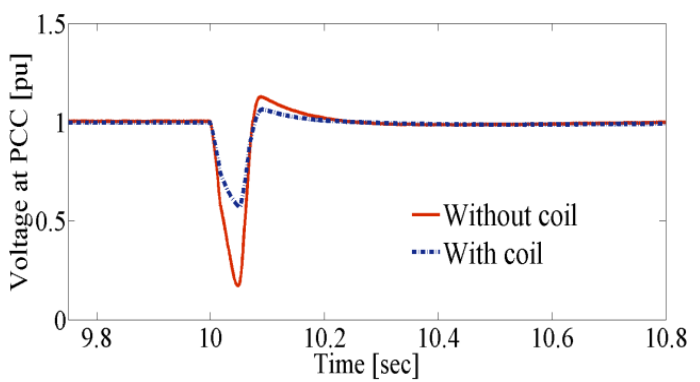

(a)

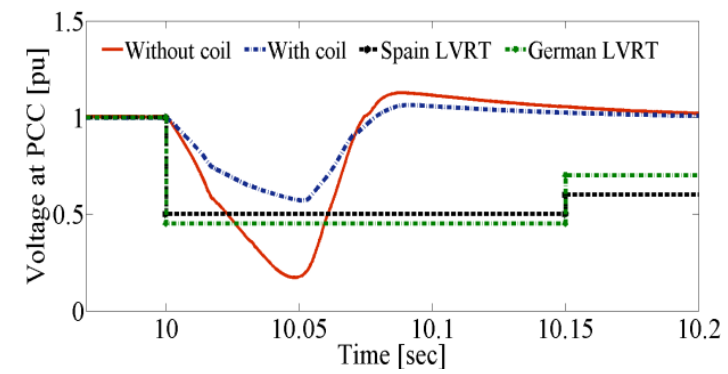

(b)

Fig. 6 Voltage profile at PCC 
Due to the fire through fault and without the connection of the coil, the active power at the PCC will drop to $-0.77 \mathrm{pu}$, indicating that the DFIG is absorbing active power from the grid and acting as a motor as shown in Fig. 7. When the coil is integrated within the DFIG converters, it can modulate the active power at the PCC to be $0.2 \mathrm{pu}$ during the fault as shown in Fig. 7. Fig. 8 shows the reactive power at the PCC without and with the integration of the coil from which the amount of surplus reactive power compensated by the coil is clearly observable.

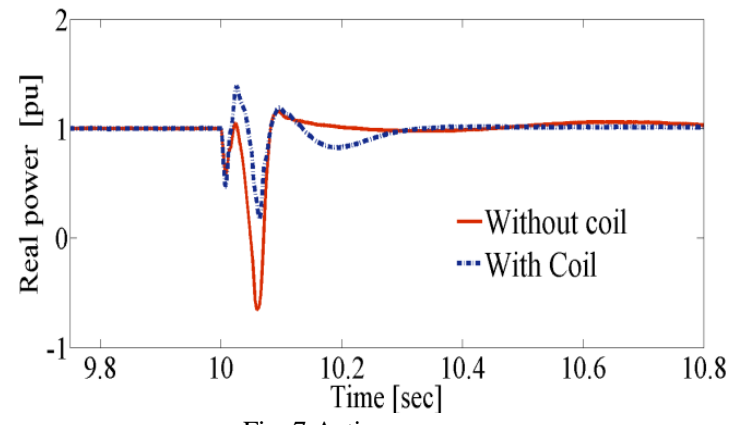

Fig. 7 Active power

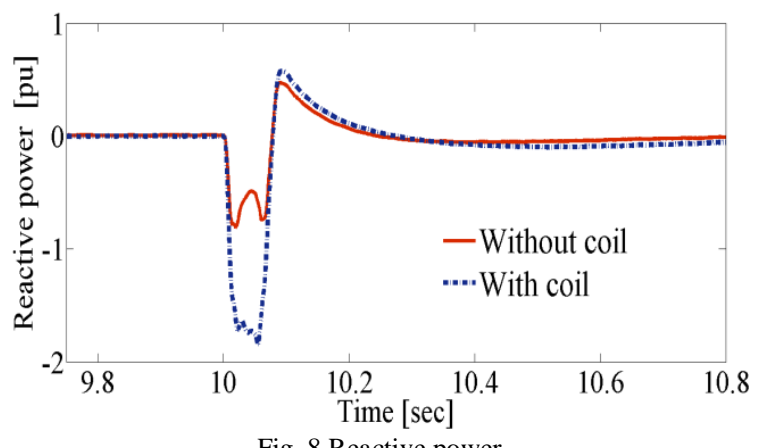

Fig. 8 Reactive power

The voltage across the dc-link capacitor when fire-through fault takes place within GSC is shown in Fig. 9 which reveals that the voltage across the capacitor drops to zero level during the fault and the voltage is recovered to its nominal level upon fault clearance.

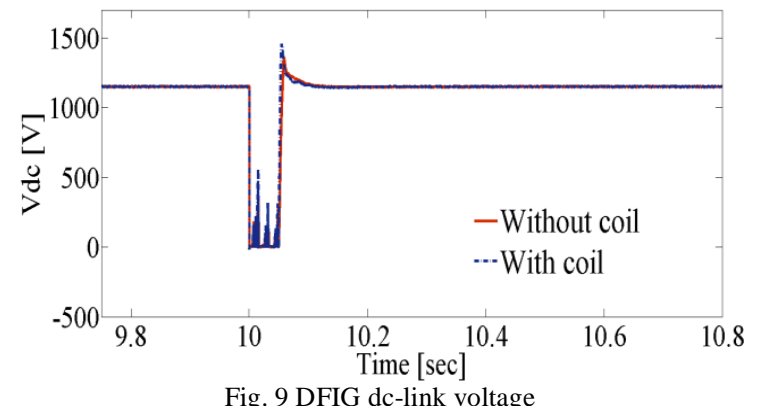

The impacts of fire-through fault on converter terminal voltages can be seen in Figs. 10.
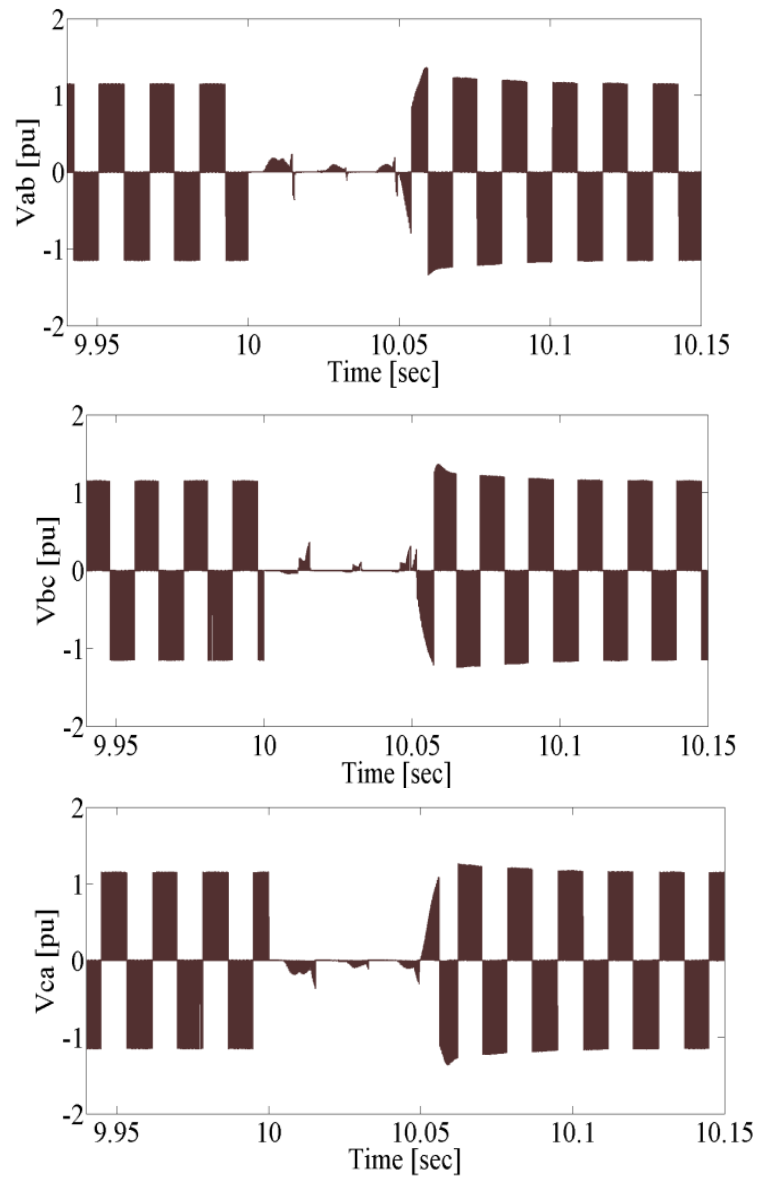

Fig. 10 Voltage across GSC terminals during fire-through in S6 within GSC.

The coil behavior when fire-through occurs within GSC can be investigated through Figs. 11 to 13 which respectively show the voltage across the coil $\left(\mathrm{V}_{\mathrm{c}}\right)$, coil current $\left(\mathrm{I}_{\mathrm{c}}\right)$, and coil stored energy $\left(\mathrm{E}_{\mathrm{coil}}=0.5 \mathrm{~L}_{\mathrm{c}} \mathrm{I}_{\mathrm{c}}^{2}\right)$ [23]. Before the fault application and during normal operating conditions, the duty cycle is maintained at 0.5 and the voltage across the coil is maintained at zero level which is corresponding to maximum coil current and rated stored energy. Upon the occurrence of fault, the proposed controller acts to reduce the duty cycle to a level less than 0.5 that creates a negative voltage across the coil and the current will be reduced accordingly allowing portion of its stored energy to be delivered to the grid. When the fault is cleared the fuzzy logic controller acts to retain the duty cycle level to 0.5 again.

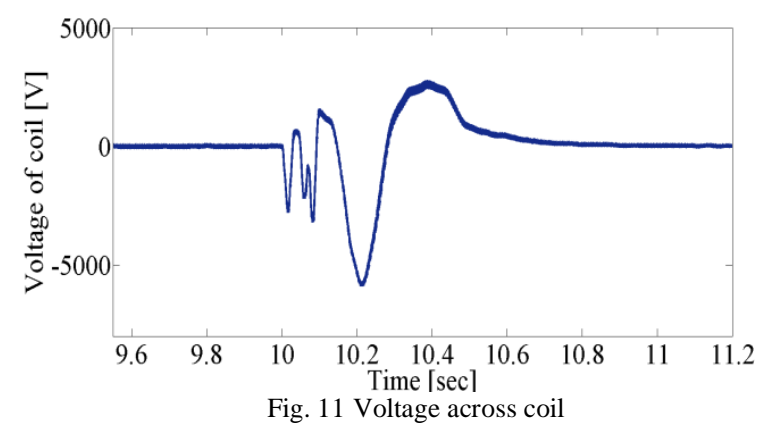




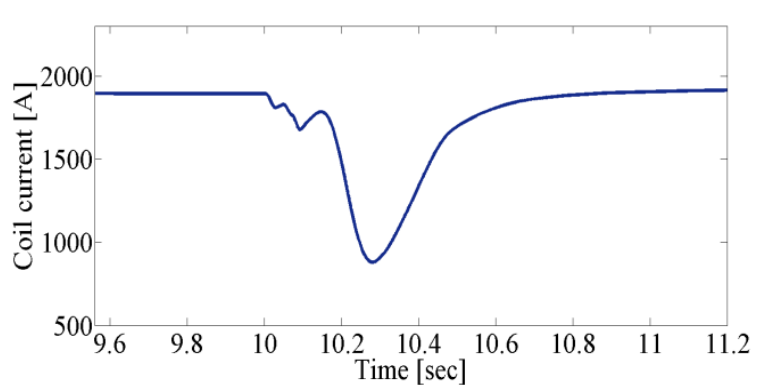

Fig. 12 Coil current

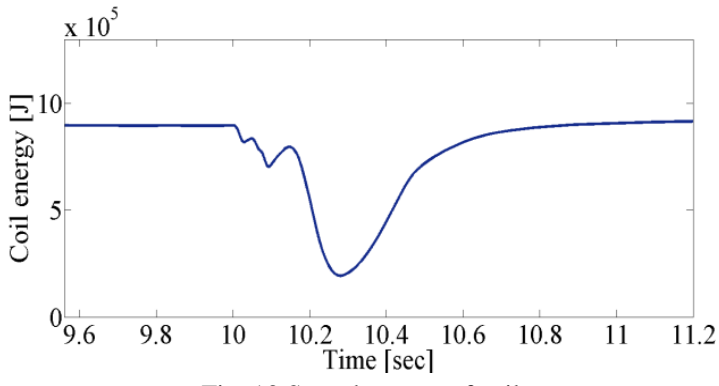

Fig. 13 Stored energy of coil

\section{CONCLUSION}

This paper presents a new topology for the DFIG converters by integrating coil within the dc-link. A fuzzy logic controller is employed to control the exchange of energy stored in the coil with the grid through controlling the duty cycle of the DC-DC chopper interfacing the coil with the converters dclink. Results show that the proposed topology can improve the dynamic performance of the DFIG-based WECS during fire through fault within GSC without the need to connect an additional FACTS device as proposed in the literature. The proposed controller is effective and easy to implement.

\section{APPENDIX}

PARAMETERS OF DFIG

\begin{tabular}{|c|c|}
\hline Rated Power & $9 \mathrm{MW}(6 \times 1.5) \mathrm{MW})$ \\
\hline Stator Voltage & $575 \mathrm{~V}$ \\
\hline Frequency & $60 \mathrm{~Hz}$ \\
\hline $\mathrm{R}_{\mathrm{S}}$ & $0.023 \mathrm{pu}$ \\
\hline $\mathrm{R}_{\mathrm{r}}$ & $0.016 \mathrm{pu}$ \\
\hline $\mathrm{V}_{\mathrm{dC}}$ & $1150 \mathrm{~V}$ \\
\hline Vpcc Base Value & $25 \mathrm{kv}$ \\
\hline
\end{tabular}

PARAMETERS OF TRANSTION LINE

\begin{tabular}{|c|c|}
\hline $\mathrm{R}_{1}, \mathrm{R}_{0}(\Omega / \mathrm{km})$ & $0.1153,0.413$ \\
\hline $\mathrm{L}_{1}, \mathrm{~L}_{0}(\mathrm{H} / \mathrm{km})$ & $1.05 \times 10-3,3.32 \times 10-3$ \\
\hline $\mathrm{C}_{1}, \mathrm{C}_{0}(\mathrm{~F} / \mathrm{km})$ & $11.33 \times 10-9,5.01 \times 10-9$ \\
\hline Line length $(\mathrm{km})$ & 30 \\
\hline
\end{tabular}

PARAMETERS OF COIL

\begin{tabular}{|c|c|}
\hline $\mathrm{L}_{\mathrm{C}}$ & $0.5 \mathrm{H}$ \\
\hline Rated $\mathrm{I}_{\mathrm{C}}$ & $2000 \mathrm{~A}$ \\
\hline
\end{tabular}

\section{ACKNOWLEDGMENT}

The first author would like to thank the Higher Education Ministry of Libya for providing him with a $\mathrm{PhD}$ scholarship at Curtin University, Australia.

\section{REFERENCES}

[1] A. M. Shiddiq Yunus, A. Abu-Siada, and M. A. S. Masoum, "Application of SMES Unit to Improve DFIG Power Dispatch and Dynamic Performance During Intermittent Misfire and Fire-Through Faults," Applied Superconductivity, IEEE Transactions on, vol. 23, pp. 5701712-5701712, 2013.

[2] M. Mohseni, S. M. Islam, and M. A. S. Masoum, "Enhanced Hysteresis-Based Current Regulators in Vector Control of DFIG Wind Turbines," Power Electronics, IEEE Transactions on, vol. 26, pp. 223-234, 2011

[3] A. M. S. Yunus, M. A. S. Masoum, and A. Abu-Siada, "Application of SMES to Enhance the Dynamic Performance of DFIG During Voltage Sag and Swell," Applied Superconductivity, IEEE Transactions on, vol. 22, pp. 5702009-5702009, 2012.

[4] J. Lopez, E. Gubia, E. Olea, J. Ruiz, and L. Marroyo, "Ride Through of Wind Turbines With Doubly Fed Induction Generator Under Symmetrical Voltage Dips," Industrial Electronics, IEEE Transactions on, vol. 56, pp. 4246-4254, 2009.

[5] M. Y. Khamaira, A. Abu-Siada, S. Islam, and M. A. S. Masoum, "Application of SMES unit to improve the overall performance of DFIG-based WECS," in PES General Meeting | Conference \& Exposition, 2014 IEEE, 2014, pp. 1 5.

[6] L. Shuhui and T. A. Haskew, "Analysis of Decoupled d-q Vector Control in DFIG Back-to-Back PWM Converter," in Power Engineering Society General Meeting, 2007. IEEE, 2007, pp. 1-7.

[7] A. Y. Abdelaziz, A. M. Ibrahim, A. M. Asim, A. H. A. Razek, and Y. G. Hegazy, "Investigation of electrical dynamics of DFIG-based wind turbines during severe symmetrical grid voltage dips," in Engineering and Technology (ICET), 2012 International Conference on, 2012, pp. 1-6.

[8] P. Ling, B. Francois, and L. Yongdong, "Improved Crowbar Control Strategy of DFIG Based Wind Turbines for Grid Fault Ride-Through," in Applied Power Electronics Conference and Exposition, 2009. APEC 2009. TwentyFourth Annual IEEE, 2009, pp. 1932-1938.

[9] X.-d. JIANG and F. Zhao, "Crowbar Control Strategy for Doubly Fed Induction Generator of Wind Farm During Power Grid Voltage Dips [J]," Power System Technology, vol. 12, p. 020, 2008.

[10] Q. Wei, G. K. Venayagamoorthy, and R. G. Harley, "RealTime Implementation of a STATCOM on a Wind Farm Equipped With Doubly Fed Induction Generators," Industry Applications, IEEE Transactions on, vol. 45, pp. 98-107, 2009.

[11] A. F. Abdou, A. Abu-Siada, and H. R. Pota, "Application of STATCOM to improve the LVRT of DFIG during RSC firethrough fault," in Universities Power Engineering Conference (AUPEC), 2012 22nd Australasian, 2012, pp. 1-6.

[12] C. Liu, Y. Kang, J. Chen, L. Kevin, X. Lin, X. Liu, et al., "Simplified Active and Reactive Power Control of Doubly Fed Induction Generator and the Simulation with STATCOM," in Applied Power Electronics Conference and Exposition, 2009. APEC 2009. Twenty-Fourth Annual IEEE, 2009, pp. 1927-1931.

[13] Y. M. Alharbi, A. M. Shiddiq Yunus, and A. Abu-Siada, "Application of STATCOM to improve the high-voltage-ridethrough capability of wind turbine generator," in Innovative Smart Grid Technologies Asia (ISGT), 2011 IEEE PES, 2011, pp. 1-5.

[14] R. M. M. Pereira, C. M. M. Ferreira, and F. P. M. Barbosa, "Comparative study of STATCOM and SVC performance on Dynamic Voltage Collapse of an Electric Power System with Wind Generation," Latin America Transactions, IEEE (Revista IEEE America Latina), vol. 12, pp. 138-145, 2014.

[15] S. W. Mohod and M. V. Aware, "A STATCOM-Control Scheme for Grid Connected Wind Energy System for Power 
Quality Improvement," Systems Journal, IEEE, vol. 4, pp. 346-352, 2010.

[16] W. Li and T. Dinh-Nhon, "Stability Enhancement of DFIGBased Offshore Wind Farm Fed to a Multi-Machine System Using a STATCOM," Power Systems, IEEE Transactions on, vol. 28, pp. 2882-2889, 2013.

[17] M. Ferdosian, H. Abdi, and A. Bazaei, "Improved dynamic performance of wind energy conversion system by UPFC," in Industrial Technology (ICIT), 2013 IEEE International Conference on, 2013, pp. 545-550.

[18] M. T. Hagh, A. Lafzi, and A. R. Milani, "Dynamic and stability improvement of a wind farm connected to grid using UPFC," in Industrial Technology, 2008. ICIT 2008. IEEE International Conference on, 2008, pp. 1-5.

[19] Y. M. Alharbi, A. M. S. Yunus, and A. Abu-Siada, "Application of UPFC to improve the LVRT capability of wind turbine generator," in Universities Power Engineering Conference (AUPEC), 2012 22nd Australasian, 2012, pp. 1-4.

[20] W. Li, L. Hao-Wen, and W. Cheng-Tai, "Stability Analysis of an Integrated Offshore Wind and Seashore Wave Farm Fed to a Power Grid Using a Unified Power Flow Controller," Power Systems, IEEE Transactions on, vol. 28, pp. 2211 2221, 2013.

[21] M. H. Ali, W. Bin, and R. A. Dougal, "An Overview of SMES Applications in Power and Energy Systems," Sustainable Energy, IEEE Transactions on, vol. 1, pp. 38-47, 2010.

[22] M. Y. Khamaira, A. M. Shiddiq Yunus, and A. Abu-Siada, "Improvement of DFIG-based WECS performance using SMES unit," in Power Engineering Conference (AUPEC), 2013 Australasian Universities, 2013, pp. 1-5.

[23] A. Abu-Siada and S. Islam, "Application of SMES Unit in Improving the Performance of an AC/DC Power System," Sustainable Energy, IEEE Transactions on, vol. 2, pp. 109$121,2011$.

\section{BIOGRAPHIES}

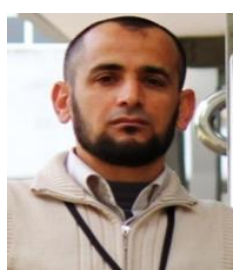

Mahmoud Y. Khamaira (S'12) received his B.Eng degree from AL-Mergheb University and the M.Sc. degree from Academy of postgraduate studies, Tripoli, both in Electrical Engineering in 1999 and 2007, respectively. $\mathrm{He}$ is currently pursuing his $\mathrm{PhD}$ study at Curtin University. His special fields of interest include superconducting magnetic energy storage, renewable energy, and smart grid

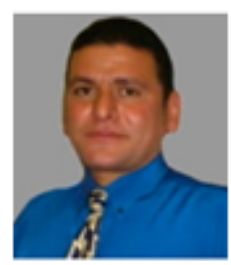

A. Abu-Siada (M'07, SM'12) received his B.Sc. and M.Sc. degrees from Ain Shams University, Egypt and the PhD degree from Curtin University of Technology, Australia, All in Electrical Engineering. Currently, he is a lecturer in the Department of Electrical and Computer Engineering at Curtin University. Editor-in-Chief for Electrical and Electronics Engineering International Journal (EEEIJ).

His research interests include power system stability, Condition monitoring, Power Electronics, Power Quality, Energy Technology and System Simulation. He is a regular reviewer for the IEEE Transaction on Power Electronics, IEEE Transaction on Dielectrics and Electrical Insulations, and the Qatar National Research Fund (QNRF). 